運動負荷STマッピングからみたST偏位の臨床的意義

\author{
東京大学医学部第二内科（指導 村尾 覚教授） \\ 川久保 清
}

\title{
CLINICAL SIGNIFICANCE OF EXERCISE ST MAPPING
}

Kiyoshi KaWAKUBO, MD

The Second Department of Internal Medicine, Faculty of Medicine, University of Tokyo

(Director: Prof Satoru Murao)

\begin{abstract}
概要 運動負荷心電図の判定上重要なST偏位については, 虚血領域や心筋の病態との関連, 偽 陽性との鑑別など不明の部分も少なくない，そこで虚血性心疾患（IHD）90例〔狭心症（AP） 46例，陳旧性心筋梗塞症 (OMI) 44例了之神経循環無力症 (NCA) 12例に, 著者の考案した胸 壁36誘導法による運動負荷試験を行ない，ST等電位線図（ST map）を作成し，冠動脈造影 $(\mathrm{CAG})$, 左室造影 (LVG), 負荷心筋タリウムシンチ（Ex. Tl）の所見之対比し, ST偏位の意 義を検討した，ST下降のみを示すもの（AP 31, OMI 17, NCA 12）ではST mapはV $\mathrm{V}_{4} \mathrm{~V}_{5}$ 中心 に分布するが, 症例に上る分布の差が文られ, 責任冠動脈病変, 虚血発生領域と対応関係がみ られた。最大ST下降の大きさとST下降領域の広さの関係は, 左冠動脈主幹部狭窄例 ( 6 例), NCA例と他のIHD群との鑑別点となつた。 ST上年例（AP 15，OMI 27）の内，AP例ではST 上界領域に一致して虚血が発生した之考方られたが，OMI例では，ST上昇領域と異常 $\mathrm{Q}$ 波の領 域, LVG上の壁運動異常部之が一致する場合が多く，これらのST上昇は壁運動異常の表現之考 えられた。一方ST上昇之同時にST下降を伴ら例（AP 15，OMI 15）では，ST下降領域はST 上昇領域との部位的関係や時間的経過から対側性变化と考支られる場合と, 虚血性ST下降と考 えられる場合があつた，本法はST偏位と虚血部位との関連の解明, 偽陽性との鑑別などに有用 と考えられた。
\end{abstract}

\section{I. 緒 言}

運動負荷心電図は虚血性心疾患の診断，予後や 治療効果の判定に広く使用されているが，運動負 荷によつて生ずるST偏位の意義については,なお 解明すべき点が少なからず残されている。その一 つは偽陽性，偽陰性の理由と偽陽性と真の陽性之 の鑑別であり，その二は今日冠動脈造影法が普及 し，造影法を行なう前に非侵襲的にその傷害の重 症度などを予測する事が望衣れるが，従来臨床的 に用いられている運動負荷法では羅患冠動脈枝を 推定する事が必ずしも容易でない事である ${ }^{1)}$. 運 動負荷の方法に関係するものとしては運動負荷量

〔昭和58年 4 月15日受稿〕
と誘導法の選択が問題となる，負荷量に関しては 多段階式負荷法が広く用いられるようになつて， 統一をはかる事が一応可能となつた，誘導の選択 については昔から多くの検討がなされているが， 上記の問題点の解決には従来の方法では不確実で ある事が明らかになつている。これに関連して最 近胸壁マッピング法㳖によつてより多くの情報を 得る事が試みられて拈り，さらに運動負荷中から 負荷後の時間的経過を追う事により情報を増す試 みもなされてきた。

著者は, 胸壁上 36 点の電極によるST偏位の等電 位図 (ST map)を作成し，その分布と時間的経過 を, 冠動脈造影 (CAG) 所見, 負荷心筋タリウム ンンチグラフィー（Ex. Tl）所見と対比し, ST 
mapの意味を冠動脈狭窄部および虚血部との関係 において検討した。

\section{II. 対象および方法}

\section{(A) 対象：}

運動負荷試験を行なつたのは臨床的に明らかな 虚血性心疾患（IHD）90例と，neurocirculatory asthenia $^{3)}$ (NCA) の症状を呈する女性12例であ る. 弁膜症, 肥大型心筋症, 脚ブロックの症例は 除外した。 その内訳は，(1）心筋梗塞の既往のな い狭心症(AP) 46例(男39例，女 7 例，年令31 73 才，平均56.4才)。（2）陳旧性心筇梗塞症（OMI） 44 例（男41例，女 3 例，年令 $28 \sim 84$ 才，平均 57.5 才)。いずれも急性期より 1 力月以上経過し, 安静 時心電図上陳旧性心筋梗塞所見を呈するるの．万 ち20例は㹨心症を合併。(1)（2）いずれも本法の誘 導法による運動負荷試験にて $0.1 \mathrm{mV}$ 以上のST偏 位がみられたものであつた（3）NCA群12例(い ずれす女性, 年令 21 - 62 才, 平均 40.3 才). 非定型 的胸痛，動悸，息切れを訴えるが，臨床的に虚血 性心疾患之考克られず，また運動負荷にてST部の 下降がみられたもの、いずれもST下降時に狭心痛 の訴えを生ぜず，基礎に高血坧その他の心血管病 を有せず，安静時心電図は正常であつた，5ち比 較的高令者の 4 例（年令 $46 \sim 62$ 才，平均 53.5 才） にはCAGを施行し正常冠動脈像が得られた。他の 8 例は冠動脈硬化症危険因子を欠く閉経前の青壮 年者（年令21〜47才，平均33.7才）であつた。

\section{（B）運動負荷法：}

身体的理由にて自転車ェルゴメーター法による 負荷（300kpmより3 分ごとに150kpmずつ増量） を行なつた 3 例を除いて, Bruceのプロトコール4) に従い,トレッドミルによる多段階式負荷を行な つた。運動負荷中止基準は，(1) 年令別予測最大 心拍数の $85 \%$ に到達，（2）進行性に増強する狭心 痛, 下肢疲労, 息切れ, （3）ST偏位発生(判定基 準は下述)とした。

(C) CAG, 左室造影（LVG）法：

IHD群90例中, 54例に括いては, Judkins法にて CAGとLVGが括こなわれた。運動負荷試験の時期 と, 心カテーテル検查の時期は47例にては 6 カ月
以内で，その間臨床症状の悪化をみなかつた。 こ れらの所見はAHAのレポート形式らにて報告さ れ，主要冠動脈枝の径の $75 \%$ 以上の狭宥を有意に とつた。また右前斜位LVGKて壁運動異常の判定 を抗こなつた。

（D）負荷心筋タリウムシンチグラフィー法 (Ex. Tl):

IHD群90例中 32 例 (AP 17例, OMI 15例) 飞お いてはEx. T1が施行された，胸部36誘導中の最大 $\mathrm{ST}$ 偏位の部位に電極を拁いて心電图をモニター し，臥位自転車エルゴメーター負荷にてST偏位， あるいは自覚症状出現時タリウム201，2mCi注射 し，1分間負荷を続けた後中止し，負荷後の撮影 を行なつた. 4 時間後再度撮影し再分布像とした。 負荷後にみられた欠損部で，4時閒後に再分布を 示すものを虚血領域と判定し，Rigoらの方法 ${ }^{6}$ に 従い虚血領域を分類した。これらの判定は放射線 科医師により独立になされた，

(E) 心電図誘導法：

アドバンス社製Lectrodeの電極をもちい図 1 のよらに，前胸部から背部にかけて36誘導点を設 定した。すなわら， $\mathrm{V}_{1}$ から $\mathrm{V}_{9}$ の 9 点の標準誘導点 を含め, 上方は第 2 助間, 下方は剣状突起下 $10 \mathrm{~cm}$, 右方は胸骨右緣，背方は胸椎の左縁の領域におい て，左前胸部に26個，左背部に10個，合計36電極 をつけた．肢誘導としてはMasonらの方法》に従 い，鎖骨下と腸骨稜上に電極を拈いた，各電極を テープで皮膚に固定し、リード線を7接点のス

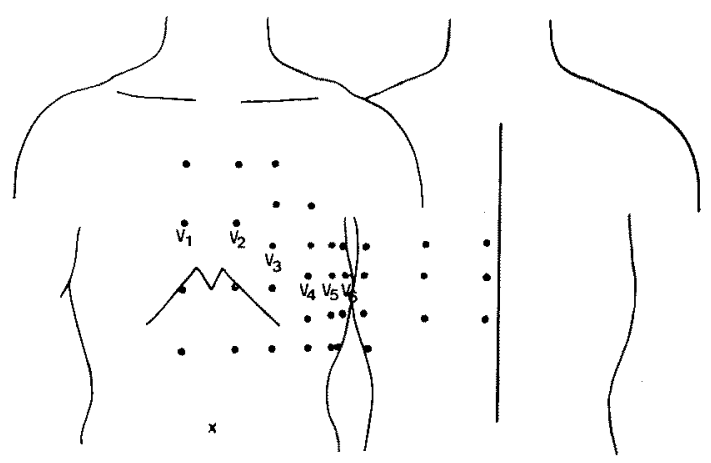

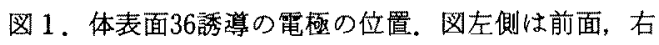
側は背面を示す（説明本文）。 


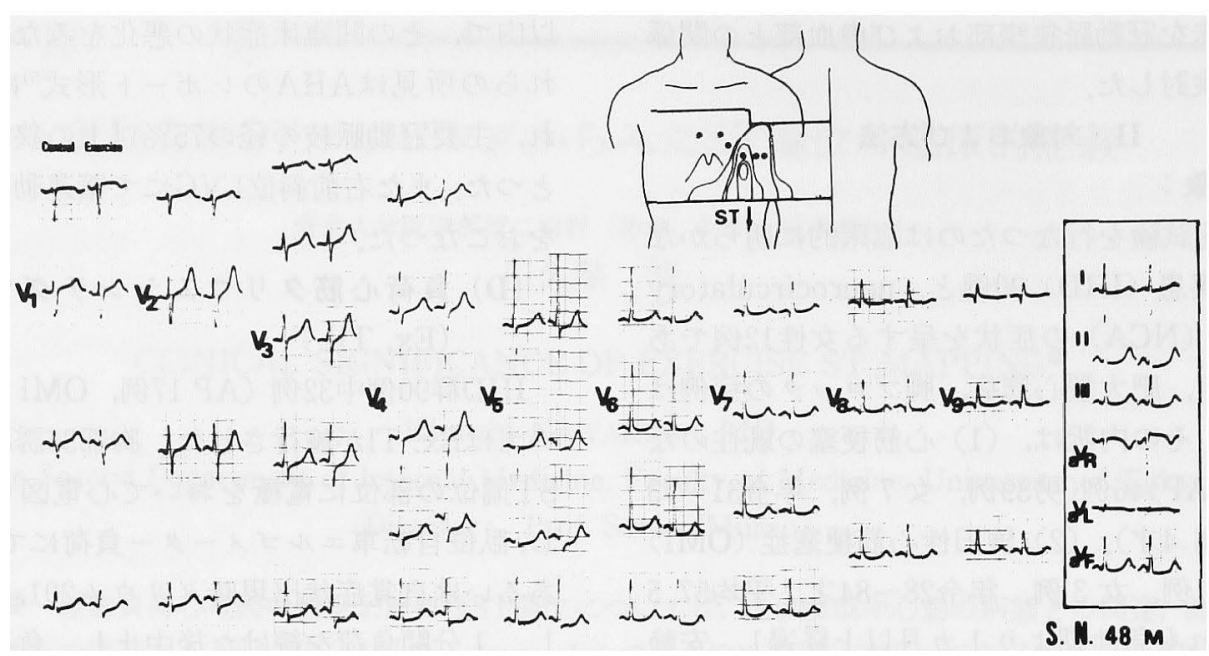

図 2. 体表面36誘導と肢誘導の運動負荷前後の心電図記録とそれにより作成したST map. ST mapの最外側の線は $1 \mathrm{mmST}$ 下降領域, 上方, 下方の直線は電極の上下端を 示し, ・印はV $V_{1} \sim V_{6}$ 誘導点を示す.

イッチボックス（1接点は肢誘導記録用）を経て, 日常臨㦿的に用いられる 6 素子心電計（フクダ電 子社製) に連結した。心電図は紙送り速度 $25 \mathrm{~mm} /$ 秒, $1 \mathrm{mV}=10 \mathrm{~mm}$ の大きさで, 運動前, 運動中 1 分ごと, 直後, 1 分, 2 分, 3 分, 5 分, 7 分後 とST偏位の運動前値にもどるまで，すべて立位で 記録した。胸部36誘導と肢誘導 1 回の記録はス イッチボックスの切り替えにより30秒以内に終了 し得た。

\section{（F）ST map作製法:}

胸部36誘導点について J 点より0.08秒にて ST 偏位を計測し，安静立位時に比べて $1 \mathrm{~mm} \quad(0.1$ $\mathrm{mV}$ ) 以上の偏位を検討の対象とした。ただしST 下降が下方傾斜型 (downslope) の場合は J 点にて ST下降を計測した。 また安静立位にてST上昇が みられ，運動にてこれが基線にもどる場合はST下 降とみなさなかつた。 これらの判定方法に従つて 各誘導ごとのST偏位量を測定し， $0.5 \mathrm{~mm}$ ごとの 等電位線図を作製し, ST mapとした（図 2 ).

な⿰ST下降領域内の電極の数と最大ST下降の 大きさの相関の統計的検討は $\mathrm{t}$ 検定にて和こな い, $\mathrm{p}<0.05$ 有意と判定した.

\section{III. 結 果}

IHD群 90 例, NCA群12例の運動負荷後にみられ
表 1. ST mapk括けるST偏位の方向とその症例数. （）内の数字はCAGを施行した例数を示す.

\begin{tabular}{|l|c|c||c|c|}
\cline { 2 - 4 } \multicolumn{1}{c|}{} & \multicolumn{3}{|c|}{ I H D } & \multirow{2}{*}{ N C A } \\
\cline { 2 - 4 } \multicolumn{1}{c|}{} & A P & OM I & Total & \\
\hline (A) ST t only & $31(23)$ & $17(10)$ & $48(33)$ & $12(4)$ \\
\hline (B) ST 1 and ! & $15(9)$ & $15(8)$ & $30(17)$ & \\
\hline (C) ST i only & 0 & $12(4)$ & $12(4)$ & \\
\hline Total & $46(32)$ & $44(22)$ & $90(54)$ & $12(4)$ \\
\hline
\end{tabular}

たST map上のST偏位の結果を表 1 に示す. ST 偏位の方向から，(A) ST下降のみ，(B) ST上㫒 に下降を伴 5，(C) ST上昇のみ，の3 群に分けら れた. 以下ST mapパターンと他検查との関連に ついて各群ごとに述べる。

（A） ST上昇を認めずST下降のみを示したも の :

本型にはIHD群48例（AP 31例，OMI 17例）と NCA群12例全例が含まれた.これらのうち検査時 狭心痛を生じたのはAP 25例（81\%), OMI 10例 (59\%)であつたが, 前述のよ5にNCA例では 1 例 もなかつた。 OMIの内訳は前壁梗塞10例，下壁梗 塞 6 例, 前下壁梗塞 1 例であつた。

(1) ST mapの分布 (IHD群48例) :

ST下降領域の分布をみると, AP, OMI とも $\mathrm{V}_{4} \mathrm{~V}_{5}$ 中心に分布する傾向にあり，47例 (98\%) で

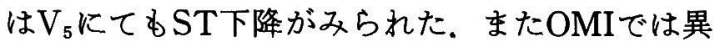




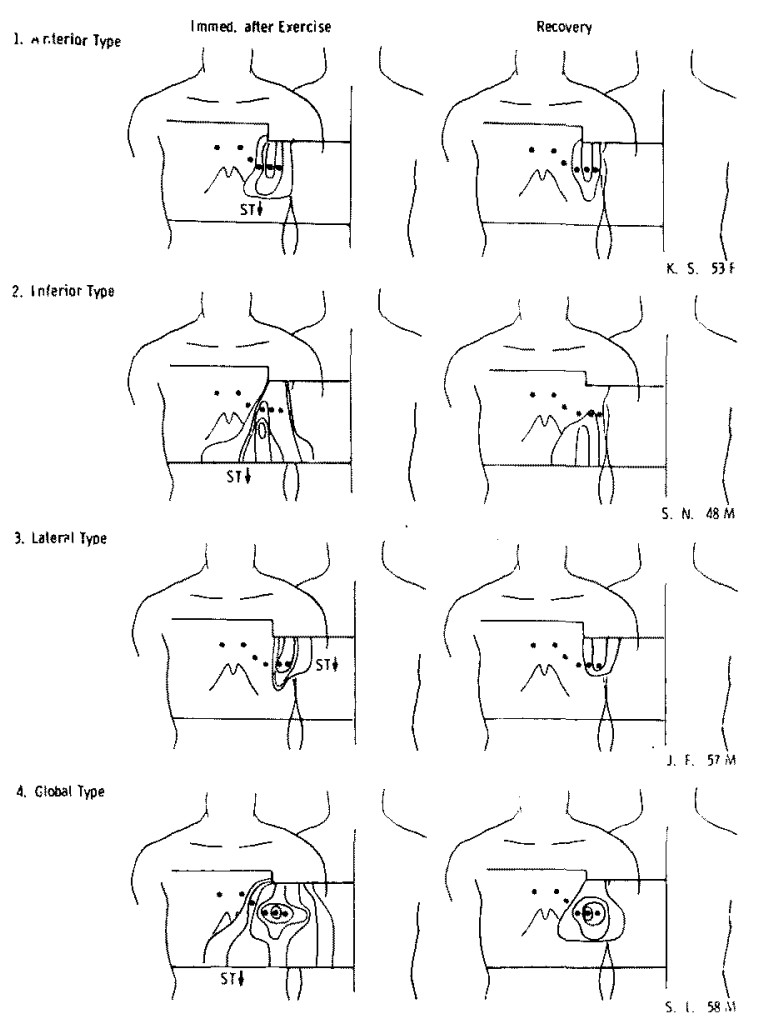

图 3.ST下降例のST map (左図は運動直後, 右図は 回復期を示す). 1 二前方型, $2=$ 下方型， 3 =側方型， 4 =広範囲型。

常Q波のない領域であつた。しかし周辺部の分布 には症例による差があり，その分布の方向と時間 的経過から次の 4 型に分類できた（図 3).（i）前 方型 (Anterior Type) (17例)； $V_{4} V_{5}$ の上下中 心にST下降領域がみられ，回復期には面積縮小し さらに前方に限局する分布を示したもので，17例 中15例では $\mathrm{V}_{4} \mathrm{~V}_{5}$ のいずれかが最大ST下降を示し た.（ii）下方型(Inferior Type) (11例)： $V_{4} V_{5}$ から末広がりに下方に分布し，最下端の誘導点(剣 状突起下 $10 \mathrm{~cm})$ に及び，回復期にさらに下方に限 局したもので, 11例中 7 例では最大ST下降点が $\mathrm{V}_{4} \mathrm{~V}_{5}$ より下方の位置であつた。（iii）側方型 (Lateral Type) ( 9 例)； $\mathrm{V}_{5} \mathrm{~V}_{6}$ から上側方に分 布する型で, 9 例中 5 例では最大ST下降点がV $V_{5}$ $\mathrm{V}_{6}$ より上方の誘導でみられた。（iv）広範用型 (Global Type) (11例)；運動直後は $\mathrm{V}_{4} \mathrm{~V}_{5}$ 中心

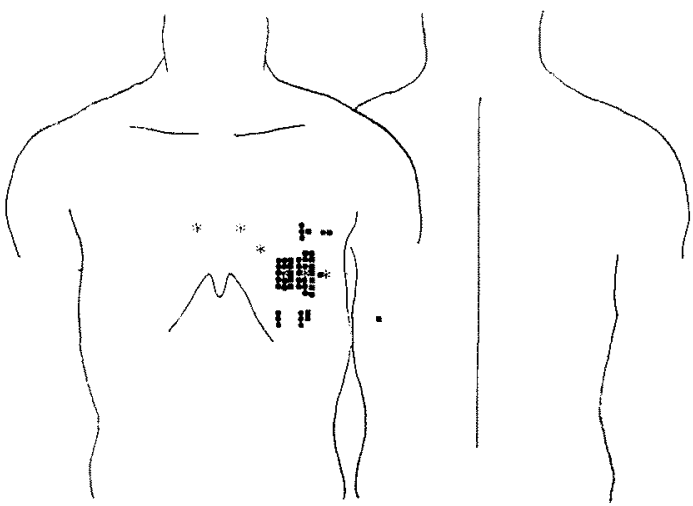

因 4.ST下降例(IHD群48例)の最大ST下降点の分布 図. ※印はV $V_{1}-V_{6}$ 誘導点を示す。 $\bullet=A P$ 例, $\square=O M I$ 例.

表 2.ST下降例のST map とCAG所見(数字は症例数 京示)，1枝=1枝狭窄，2枝=2枝㹨窄，3校=3

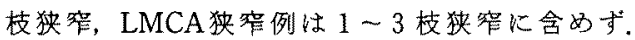
LMCA涨窄例 6 例のうち 3 例はLMCAKの及狭窄の あつた例である。

\begin{tabular}{|c|c|c|c|c|c|c|c|}
\hline ST thap $\quad C A G$ & 1 枝 & 2 枝 & 3㩽 & LMCA & LAD & LOX & RCA \\
\hline (1) 餀方型(13 & 3 & 8 & 2 & 0 & 12 & 6 & 7 \\
\hline (2) 下方型(5) & 2 & 3 & 0 & 0 & 4 & 2 & 2 \\
\hline 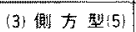 & 0 & 3 & 2 & 0 & 3 & 5 & 4 \\
\hline (4) 苰轮闻㷱10 & 0 & 2 & 2 & 6 & 7 & 7 & 4 \\
\hline
\end{tabular}

に前方から下方むで広く分布するが，回復期には ST下降領域縮小寸ると前方に限局し，上述の前方 型に似る分布を示す型で, 11 例すべて $V_{4} V_{5}$ のいず れかが最大ST下降を示した。

（2）最大ST下降点の分布 (IHD群48例)：

胸部36誘導に和ける最大ST下降点の分布をみ ると（図 4)，AP, OMI とに $\mathrm{V}_{4} \mathrm{~V}_{5}$ の周辺に分布 し， $V_{5}$ の頻度が最大 $(18 / 48=38 \%)$ であった。し かし15例に扮いては $\mathrm{V}_{4} \mathrm{~V}_{5} \mathrm{~V}_{6}$ の上方，あるいは下 方にずれて最大ST下降がみられた。

(3) ST map とCAG (IHD群33例):

IHD群のうらCAGを施行した33例についてST mapパターンと有意狭窄冠動脈枝との関係をみる と表 2 の様になつた。前方型13例中12例では左前 下行枝（LAD）に有意の狭窄がみられた（LAD 1 枝狭窄 3 例を含む).下方型 5 例でも冠病変の分布 は前方型と注济同様であつたが，右冠動脈(RCA) 
表 3.ST下降例のST map とEx.T1による虚血領域 (数字は症例数を示す). ※前壁には前側壁, 前壁中隔

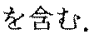

\begin{tabular}{|c|c|c|c|c|}
\hline \multirow{2}{*}{ St miak. } & \multicolumn{4}{|c|}{ 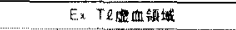 } \\
\hline & 而 & 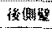 & 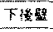 & 心尜部 \\
\hline 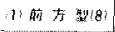 & 6 & 2 & 0 & 1 \\
\hline (2)下方整:2 & 0 & 0 & 2 & 0 \\
\hline 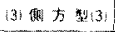 & 2 & 3 & 0 & 0 \\
\hline 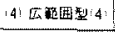 & 3 & 2 & 0 & 2 \\
\hline
\end{tabular}

1 枝狭窄が 1 例に文られたが，他にLAD 1 枝狭 窄例が 1 例あつた。側方型は全例左回旋枝 (LCX) 狭窄のある多枝狭窄例であつた。広範囲型10例中 6 例は左冠動脈主幹部（LMCA）狭窄例であり， 他の 4 例はLADを含む多枝病変例であつた。

(4) ST mapとEx. Tl (IHD群20例):

IHD群のらちEx. TIを施行した20例について ST map ハターンと一過性虚血領域と対比した。 虚血領域はRigoらのの分類に従い前壁, 後側壁, 下 後壁，心尖の 4 領域にわけた(表 3 )。3例にては 一過性虚血の所見が得られず，17例について検討 した。前方型では前壁（6/8），下方型では下後壁 $(2 / 2)$ ，側方型では後側壁 $(3 / 3)$ ，広範囲型では前 壁 $(3 / 4)$ ， あるいは心尖部 $(2 / 4)$ に再分布像之比 して一過性の欠損像がみられた。

（5）ST下降領域の広さと最大ST下降の大ささ との関係 (IHD群33例) :

IHD群のらちCAG支施行した33例について最 大ST下降の大きさ $(\mathrm{X}(\mathrm{mm}))$ と，体表面36誘導 のうちSTが $1 \mathrm{~mm}$ 以上下降した領域に含まれる誘 導電極の数 $(\mathrm{Y})$ を比べると, $\mathrm{Y}=4.94 \times+1.67$ $(r=0.78, p<0.001)$ の有意の相関が得られ，ST 下降の程度が大き程ST下降領域が広いという 関係が示された (図 5 左)。最大ST下降の大ささ $3 \mathrm{~mm}$ 以上, ST下降領域 18 ב 以上の範田には LMCA狭窄例 6 例全例がはいつた。

(6) NCA例のST mapとの対比:

NCA群12例中, 負荷直後よりST下降が办られ たもの 6 例, 回復期になつて始めてST下降がみら れたもの6例であつたが，ST mapパターンは前 述の下方型 (10例)，あるいは前方型（2例）を示 した。しかしこれらのST mapは, IHD群のよらに
1HO
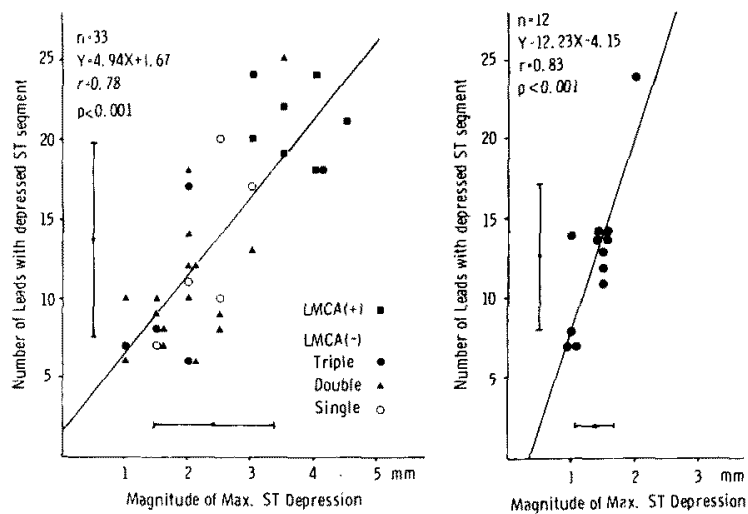

图 5.ST下降領域内の誘導電極の数 $(\mathrm{Y})$ と，最大ST 下降の大きさ $(\mathrm{Xmm})$ との関係：(左図はIHD群33例, 在図快 NCA群12例) LMCA (十)=左冠動脈主幹部㹟 窄例，Triple $=3$ 枝狭咋例，Double $=2$ 枝狭榨例， Single $=1$ 枝狭窄例.

負荷後回復期に明らかな縮小をみず，そのま京の 大ささで持続する㑯向にあつた(図 6).NCA群に ても最大ST下降の大きさ $(\mathrm{X}(\mathrm{mm}))$ と体表面 36 誘導のうら，STが $1 \mathrm{~mm}$ 以上下降する領域に含ま れる電極の数 $(Y)$ を比べると有意な相関 $(Y=$ $12.23 \times-4.15, \mathrm{r}=0.83, \mathrm{p}<0.001)$ が得られたが (図 5 右), IHD群比して, ST下降の広さは同程

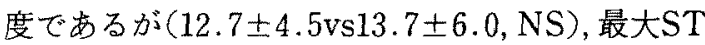

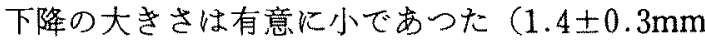
vs2.4 $\pm 1.0 \mathrm{~mm}, \mathrm{p}<0.01)$ またIHD群でNCA群 と闰程度の最大ST下降の大きさ（1１.5mm） 示した13例と比較すると，NCA群の方がST下降 領域は有意に広かつた（12.7土4.5 vs $8.6 \pm 2.8$, $\mathrm{p}<0.02)$.

(B) ST上昇とST下降を示したもの：

本型はAP 15例とOMI 15例でみとめられた。前 者の中 11 人（73\%）娭查時狭心痛を訴光たが， 後者では検查時狭心痛を訴点たものはなかつた。 以下AP群 $(\mathrm{BA})$ とOMI群 (Bo）とを別に述べる。

\section{(BA) AP群}

本群15例のちち11例惊長時間心電図にて自然発 作（ST上昇）を確認し得た異型狭心症例であり， 自然発作時のST上昇を示した誘導は運動負荷時 


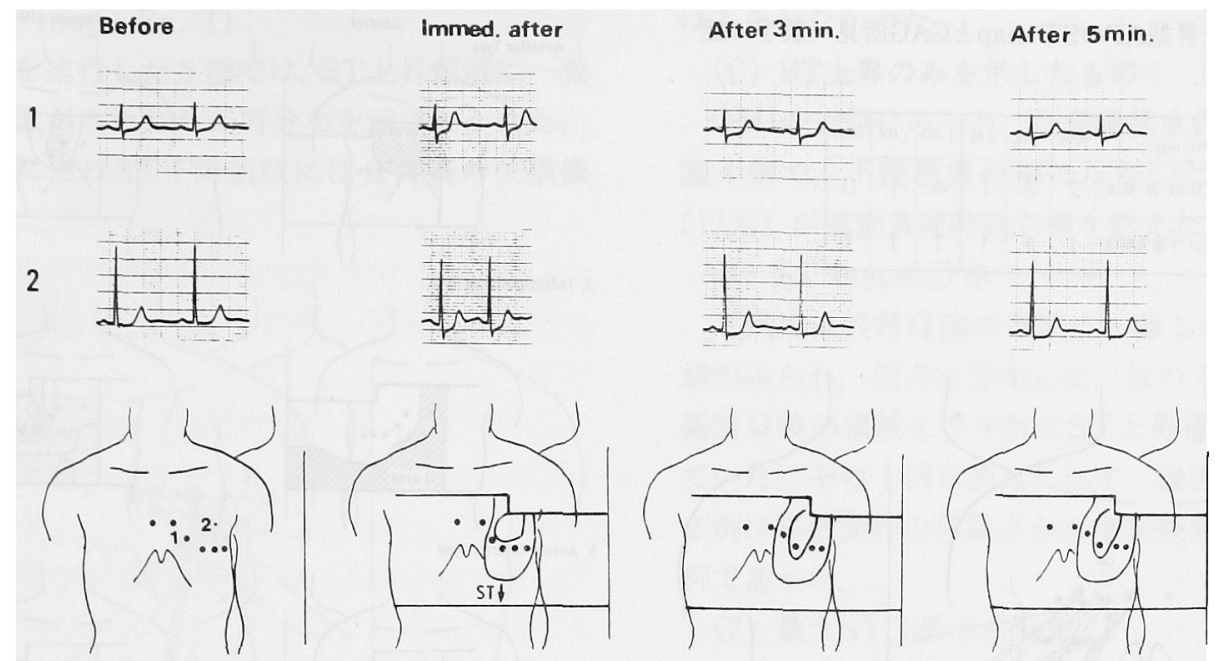

図 6.NCA例（正常冠動脈像を示した53才, 女珄）のST map所見（直後より5 分後 まで). 図中 1 はV $V_{3}, 2$ はV 5 の 1 助間上方の心電図を示す。

にST上昇のみられた誘導と一致した。

(1) ST mapの分布:

$\mathrm{ST}$ 上昇領域の分布により，前方型（8 例）と下 後方型（7 例）に分ける事ができた（図 7 ).これ らの例のST上昇領域は, 前述のST下降例のST mapの分布（図 3 ）と異なり， $\mathrm{V}_{4} \mathrm{~V}_{5}$ から右上方あ るいは下方に離れた比較的限局した分布を示し， 前方型と下後方型の分布の差が明瞭であつた。 ま たいずれの例もST下降領域を伴つていたが，ST 下降がST上昇と同時に出現し，同時に消失するも の 7 例（図 7 anterior 1, infero-posterior 1), ST 下降がST上昇消失後にも ST上昇領域以外に残存 するもの 7 例 (図 7 anterior 2),ST下降がST上昇 に先行したもの 1 例（図 7 infero-posterior 2）で あつた. 前者と後 2 者では, 後者の方がよりST上 昇領域に近接し，広いST下降領域を示した。

（2）最大ST偏位点の分布：

胸部36誘導における最大ST上昇点之同時に伴 う最大ST下降点の分布をみると（図 8), 前述の $\mathrm{ST}$ 降のみの例の $\mathrm{V}_{4} \mathrm{~V}_{5}$ 中心と異なり, $\mathrm{V}_{2} \mathrm{~V}_{3}$ 周辺 あるいは下後方が中心であつた。また 7 例では背 部にて最大 ST上昇あるいは最大ST下降を示し た.

(3) ST map とCAG :

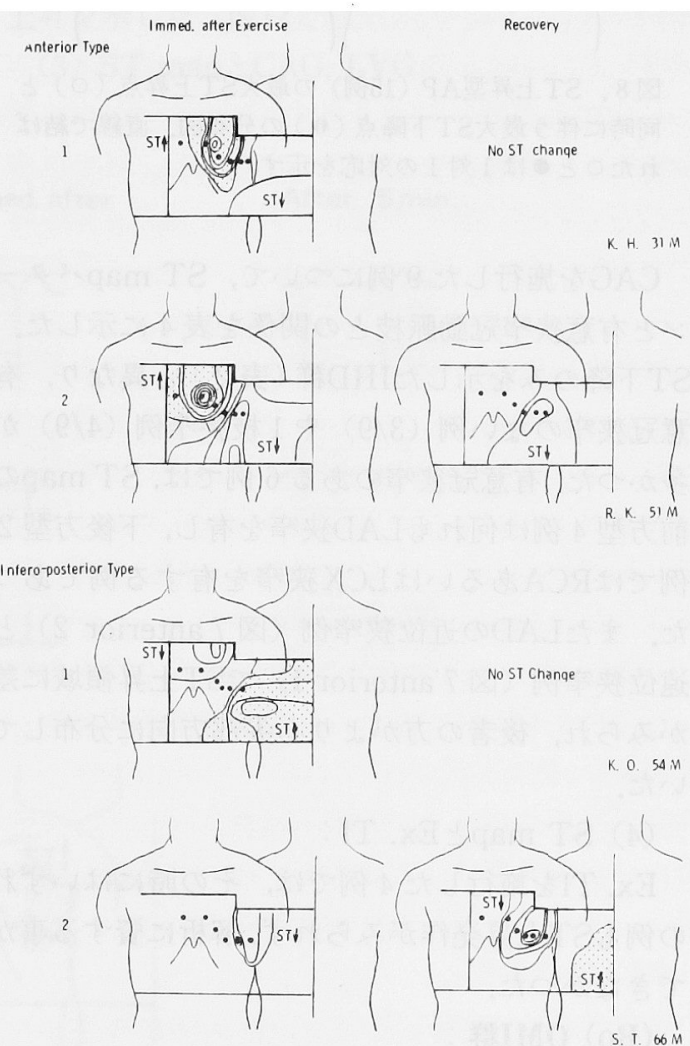

図 7. ST上昇型APのST map (左図は運動直後, 右図 は回復期を示す). 点線領域はST上算領域を示す。 
表 4.ST上昇型APDST map とCAG所見（数字は症 例数を示す).

\begin{tabular}{|c|c|c|c|c|c|c|}
\hline ST map CAG & 正常 & ，啧 & 2 校 & $\angle A D$ & Lox & $R \subset A$ \\
\hline (1) 前方型 6 & 2 & 3 & 1 & 4 & 1 & 0 \\
\hline (2) 下你方型(3) & 1 & 1 & 1 & 1 & 1 & 1 \\
\hline
\end{tabular}
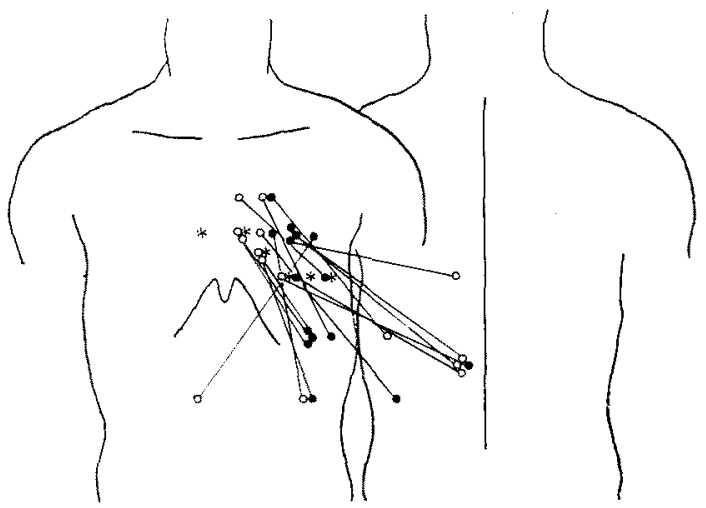

图 8, ST上昇型AP (15例) の最大ST上算点(0) と 同時に伴亏最大ST下降点（・）の分布図。直線で結ば れたのと・は1対 1 の対応を示す。

CAGを施行した 9 例について，ST mapパター ンと有意狭窄冠動脈枝との関係を表 4 に示した。 ST下降のみを示したIHD群（表 2）と異なり，有 意冠狭窄のない例 (3/9) や1枝狭窄例 $(4 / 9)$ が 多かつた。有意冠狭窄のある 6 例では, ST mapの 前方型 4 例は何れもLAD狭窄を有し，下後方型 2 例ではRCAあるいはLCX狭窄を有する例であつ た。またADの近位㹨窄例（図 7 anterior 2) と 遠位狭窄例（図 7 anterior 1) でST上昇領域に差 がみられ，後者の方がより心尖部方向に分布して いた。

(4) ST map ŁEx. T1 :

Ex. Tlを施行した 4 例では，その時にはいずれ の例もST上笔発作がみられず，解析に資する事が できなかつた。

\section{(Bo) OMI群 :}

本群は前壁梗塞 4 例，下壁梗塞 9 例，前下壁梗 塞 2 例で，下壁梗塞には高位後壁梗塞の 2 例が含 东れた。
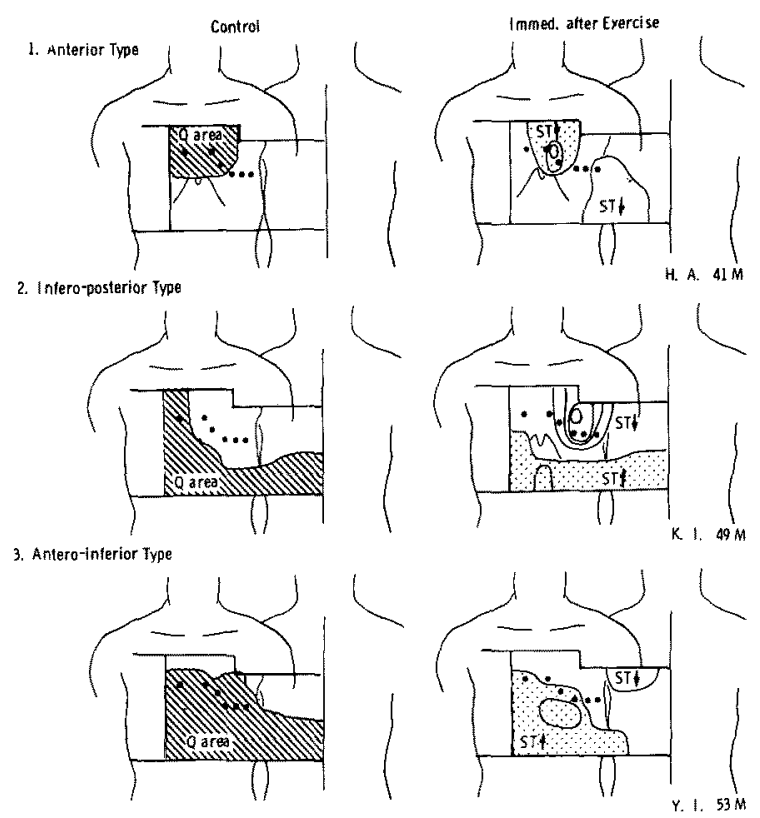

図 9.ST上舁・下降型OMIのST map (左図は運動前, 右图は運動直後を示す)。斜線領域は異常 Q波の镇域, 点線の領域はST上昨領域を示す。

\section{(1) ST mapの分布：}

$\mathrm{ST}$ 上昇領域の分布により，前方型( 4 例)，下後 万型 ( 9 例)，前下万型 ( 2 例) に分類する事がで きた(図 9).いずれの例もST上舁領域は異常Q波 の領域に含まれた。また同時に伴うST下降領域は $\mathrm{ST}$ 上昇と同時に出現し，回復期に同時にもどつ た.

(2) 最大ST偏位点の分布:

これらの例の胸部36誘導における最大ST上昇 点と同時に伴う最大ST下降点の分布をみると(因 10), ST上昇, ST下降を示したAP例(図 8) と同 様にいずれす $V_{4} V_{5}$ から離れた分布を示した。

(3) ST map とCAG, LVG:

CAGを施行した 8 例では，有意冠狭窄を示さな かつた 1 例を除いて,ST上昇領域の責任冠動脈枝 とみなされる冠動脈枝に狭窄がみられた（6 例は $100 \%$ 㹟窄).ST下降領域の責任冠動脈枝には 3 例 に扮いて有意の狭窄がみられなかつた。右前斜位 LVG上のakinesis，あるいはhypokinesisの部位と ST上昇領域は，8例全例にて一致がみられた。 
(4) ST mapとEx. Tl :

Ex. Tlを施行した 5 例では, ST上昇領域に一致 して久損像がみられたが再分布を示さなかつた。 また 4 例にてはST下降領域には負荷後の欠損像

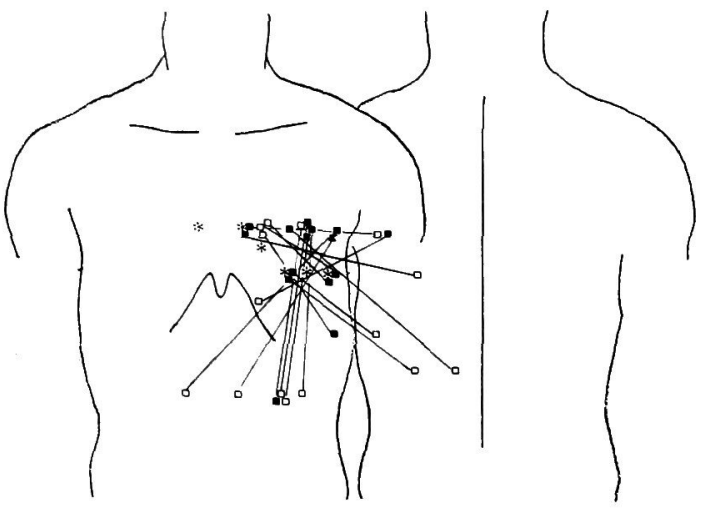

図10.ST上昇・下降型OMI (15例) の最大ST上昇点 （口）と同時に伴う最大ST下降点 (ロ)の分布図. 直線 で結ばれたロと・は 1 対 1 の対応を示す。
はみられなかつた。

(C) ST上昇のみを示したもの：

OMIの12例にみられ，前壁梗塞 8 例，前下壁梗

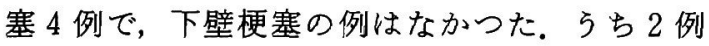
（17\%）が運動負荷時狭心痛を訴えた。

(1) ST mapの分布：

8 例では異常 $\mathrm{Q}$ 波の領域に一致してST上昇領 域がみられ，前方に分布した。他の 4 例では一部 異常 $\mathrm{Q}$ 波の領域よりずれてST上昇領域が分布し ていた，その 1 例を図11に示す。後者 4 例のうち 2 例は自然発作の確認された梗塞後異型狭心症の 例であつた。

(2) 最大 $S T$ 上昇点の分布 :

これら12例における胸部36誘導中の最大ST上 昇点の分布は， $\mathrm{V}_{3} \mathrm{~V}_{4} \mathrm{~V}_{5}$ およ゙そと方をしめ， 5 例 (42\%) は, $\mathrm{V}_{3} \mathrm{~V}_{4} \mathrm{~V}_{5}$ の上方の誘導にて最大 $\mathrm{ST}$ 上昇を示した（図12）.

(3) ST map とCAG, LVG :

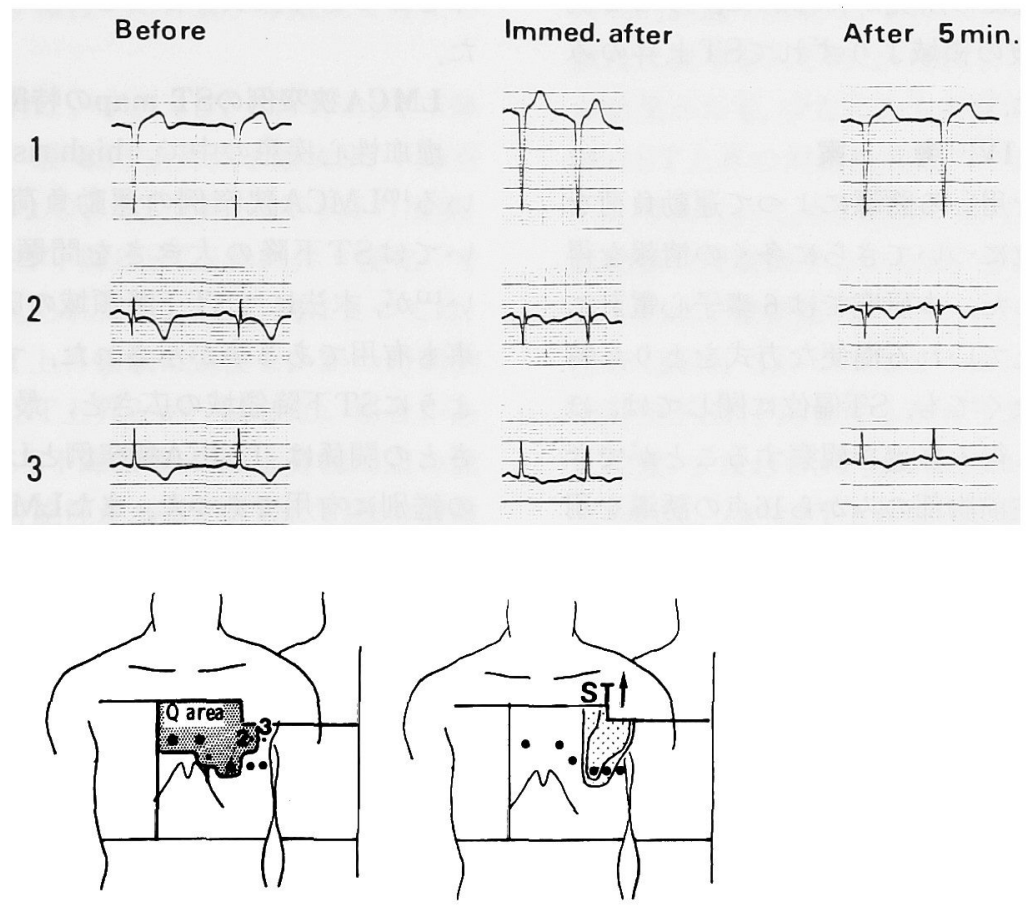

図11. ST上昇型OMIの 5ち異常 $\mathrm{Q}$ 波領域（Q area）とST上昇領域の不一致例（左図 は運動前, 右図は運動直後を示す). 因中 1 は $V_{3}, 2$ は $V_{5}$ の 1 肋間上, 3 は $V_{6}$ の 1 肋間 上の心電図を示す。 


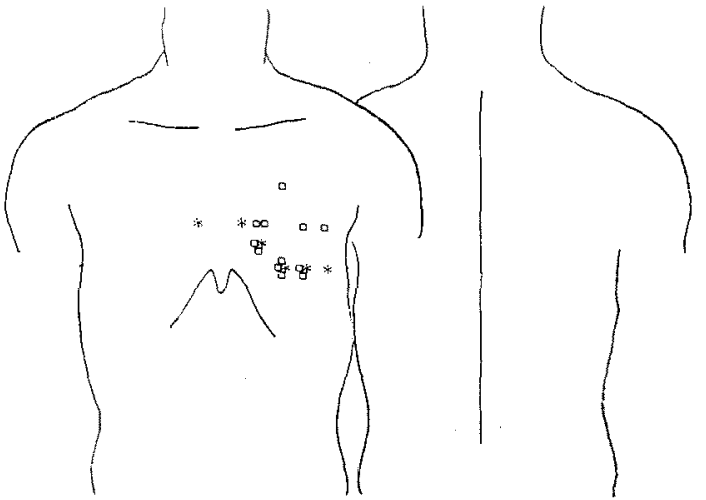

図12，ST上昇型OMI（12例）の最大ST上鼎点（口） の分布図。

CAG, LVGを施行したのは 4 例のみであつた が, ST上昇領域の責任冠動脈枝に狭窄がみられ, また右前斜位LVG上，前側壁から心尖部にかけて akinesisないしdyskinesisがみられた。

(4) ST map ¿Ex. T1 :

Ex. Tlを施行したのは 3 例のみであつたが，梗 塞周辺の一過性虚血の所見が得られた。 5 ち 2 例 は前述の異常 $\mathrm{Q}$ 波の領域よりずれてST上昇のみ られた例であつた。

\section{IV. 考 案}

胸壁上の36点を用いる誘導によつて運動負荷を 招こない，ST偏位についてさらに多くの情報を得 る可能性を検討した，本研究では 6 素子心電計に 多誘導を切り換えていれる簡便な方式をとり，特 殊な装置を用いなくても，ST偏位に関しては，注 活連続的とみなし得る経過を観察することができ た. Fox $5^{8)}$ は, 左前胸部のみから16点の誘導を用 いて運動負荷試験を行ない, 従来の誘導法に此べ てsensitivityの向上がみられたとしているが，ST 上昇部やそれに伴らST下降領域の検出には, 背部 和上び前胸部下方へも電極をつける必要性がある 事が，本法の36誘道法で明らかにされた。

\section{ST下降の意義 :}

運動負荷にてST下降のみがみられた例では， $\mathrm{AP}, \mathrm{OMI}$ を的降領域は $\mathrm{V}_{4} \mathrm{~V}_{5}$ の心尖部近辺 を中心にしてみられ（図 3)，48例中47例（98\%） ではV $V_{5}$ 誘導にてST下降がみられた。このV $V_{5}$ の高
陽性率は従来の報告》) と一致し，少数誘導法では ST下降誘導から虚血領域を推定するのが困難で ある事”と関連があり，ST下降が血管床の少ない 心尖部中心の心内膜下虚血の結果生ずるためと考 えられた。Foxらが示す8)棣な，標準誘導点 $\left(V_{1}\right.$ 一 V $V_{6}$ ) 含まず，その上方めるいは下方に限局し た領域にのみST下降を示した例は経験されなか つた。

この群ではST下降の検出という意味では本法 が特にすぐれているものではないが，ST mapの 分布は症例によつて一様ではなく，その区分は Ex.T1の虚血領域，罪患冠動脈枝との間に少なか らず関連性がみられた。しかし本対象は多枝狭窄 例が多く，变たST下降領域と狭窄冠動脈枝の灌流 領域とは合致しない例も少なからずあり，むしろ Ex. Tlによる虚血領域とよくあう結果が得られ た. 冠動脈の解剖学的位置, 体型の個人差やsteal 現象9の関与が合致しない場合の原因之考方ら れ，ST下降領域は，心筋の機能的な一過性虚血分 布をよりよく反映することによるものと考えられ た.

\section{LMCA狭窄例のST mapの特徵：}

虚血性心疾害の中で, high risk groupとされて いる ${ }^{10} \mathrm{LMCA}$ 狭窄例の運動負荷試験の特徴汇つ いてはST下降の大きさを問題にした報告が多 い'11が，本法にてST下降領域の広さをも考慮する 事も有用である事が示された。すなわ罒 5 左の ようにST下降領域の広さ之, 最大ST下降の大き さとの関係は, LMCA狭窄例とLMCA非狭窄例と の鑑別に有用であつた。 またLMCA狭窄のない 3 枝狭窄例ではST下降領域が狭く, ST下降度も比 較的小さい例もあり，このST map上の特徽は， LMCA狭窄そのbのが関係し，運動負荷による広 範囲な虚血の結果生じたものと考党られた。

\section{NCAにおけるST mapの特徵：}

従来上り若年女性にて運動負荷心電図の偽陽性 が多いとされている ${ }^{12)}$. NCA例で，ST部が1mm 以上下降を示した12例にて,ST下降領域の広さと 最大ST下降の大きさを検討した. IHD群に比して これらの例ではST下降領域の広さの割に最大ST 
下降の大きさが小さく，また運動負荷後のST mapの経過も異なつた。この所見は本法により明 らかにされた新しい知見であり，IHD群のST下降 との有用な鑑別点になること，またこれらのNCA 群のST下降の機序は虚血によるもの ${ }^{13)}$ ではなく， 運動にて変化した自律神経系の関与などを考学さ せる結果であることを示唆するすのと考克られ た. 。

\section{APにおけるST上昇の意義：}

従来労作にては発作は誘発されないといわれて いた異型狭心症でも，運動負荷にてST上昇発作が 誘発される事が最近報告されている ${ }^{14)}$. 本型のST 上昇領域は従来の自然発作の検討からも推定され るように，前上部，あるいは下後方部に限局して 分布して打り，狭窄冠分枝から予想される領域と 比較的よく一致したが, ST下降のみを示したIHD 群と異なり，有意冠狭窄のない例もみられた。以 上の事実は，正常冠動脈例でもスパズムがみら れ15)，また冠動脈スパズムが冠狭窄の部位に一致 して生ずるという報告 ${ }^{16)}$ に合致する結果と考克ら れた。

一方これらの例はいずれるST上昇時にST下降 を伴つていたが，最大ST上昇点と最大ST下降点 の分布（図 8) 和上び, ST上昇とST下降の出現, 消失時相から，ST下降はST上昇に伴ら変化 ${ }^{17)}$ ある可能性が考兄られた。しかし症例によつては， ST下降領域がST上昇領域に近接し，かつ時間的 経過でST下降とST上昇とが一致しない場合があ つた。この場合ST下降領域はST上昇部周辺の虚 血の反映である可能性があるが，Ex. Tl法の情報 が得られず推測の域を出ない。

$\mathrm{ST}$ 上昇，下降を同時に伴ら例では背面で最大 ST上昇, ST下降をみる場合も多かつた。かかる場 合には背面電極を欠く胸壁マッピング法では解釈 を誤る恐れが大さい．ST上昇部とST下降部の部 位的関倸は，背面にも電極を和いた本法によつて より正確に把握されると考学られた。

\section{OMIにおけるST上昇の意義：}

ST上昇を示したOMIはST下降を伴ら場合 （Bo）と，伴わない場合（C）の2 群に分けられた
が，いずれの場合もST下降のみを示したOMIに 比して運動負荷狭心痛を訴える事が少なかつた。 本法では一部の例外を除いてST上昇領域は異常 Q波の領域の中に含まれ，またLVG上の壁運動異 常を示した部位と一致した。これは文献成績 ${ }^{181}$ と 同様であり，ST上昇は新たに生した虚血を意味す るむのでなく，安静時より存在する壁運動異常に 関係すると考えられる所見である。しかし一部の 例（図11）では異常Q波の領域よりずれたST上昇 分布を示す事があり，Ex.T1の所見からる，この 様なST上昇は梗塞周辺の虚血 ${ }^{19}$ を考学させるも のであつた。以上のようにST上昇部と異常 $\mathrm{Q}$ 波の 部位的関係はOMIKおけるST上昇の解釈に重要 であり，ぞの正確な関係の把握にも本法は有用と 考壳られる。

一方OMIにてST上昇と共にST下降を伴ら例 については, ST下降領域は別の領域の虚血を示唆 するとの意見もみられる181 201. しかし本研究で は, ST下降領域とST上昇領域は, 運動負荷後同じ 時間的経過で消裉し，またST下降領域の責任冠動 脈枝に狭窄をみとめない例 $(3 / 8)$ も方，Ex.TI の結果からも, 少なくとも本研究の症例ではST下 降はST上昇の対側性変化 ${ }^{17)}$ である可能性が大き いと考党られた.ST上昇のみの例は前壁の比較的 広範囲の梗塞例であつたが，ST上昇にST下降を 伴ら例は下壁梗塞例が多かつた。最大ST上昇点の 分布（図10，12）でみるように，OMIに和けるST 上昇例がST下降を伴らかどらかは, 梗塞の大ささ と位置, すなわらST上昇領域の差によるものと考 えられた。实たST上昇のみを示した例の最大 $\mathrm{ST}$ 上昇点（図12）は， $V_{3} V_{4} V_{5}$ 预よびその上方にみら れ，ST下降のみを示した例の最大ST下降点（図 4) がV $V_{4} V_{5}$ 拈よびその上下にみられたのと異なつ た。これはOMIに挌けるST上昇誘導の検出上重 要な点と考学られた。

\section{V. 結 論}

独自の方法を用いた体表面36誘導による運動負 荷ST map と, CAG, LVG, Ex. Tl法と対比方 事により，虚血部位診断上の問題点, NCA例のST 下降との鑑別の可能性について検討し，以下の新 
しい知見が得られた。

(1) ST下降のみを示すものでは, , AP, OMI むにST下降領域は $\mathrm{V}_{4} \mathrm{~V}_{5}$ 中心に分布するが，症例 により分布の偏りがみられ，その偏りが責任冠動 脈病変, 虚血発生領域と対応関係がみられた。

（2）ST下降領域の広さと最大ST下降の大きさ の関係は，LMCA狭窄例と他のIHD群，またNCA 群とIHD群との鑑別に有用であると考岳られた。

（3）ST上昇と下降が併存する例では，ST下降 が, ST上昇の対側性変化と考光られる場合之, 虚 血性ST下降と考えられる場合とがあり，ST map が両者の鑑別上有用である可能性が示唆された。

（4）ST上昇を示すAPではST上昇領域に一致 して虚血が発生したと考えられる結果を得たが， OMIにおけるST上昇の多くは壁運動異常の表現 と考光られた。

（5）本法は通常の心電計を利用出さる簡便な方 法であり，日常臨床に広用して，冠動脈病変の重 症度や狭窄分枝の推定, NCAとの鑑別に利用しう るものと考えられる。

謝辞 シンチグラフィー検查に御協力くださつた東京大 学放射線科 领尾正宏教授，町田喜久雄助教授はじめ教室 員の方々に感謝いたします。

\section{文献}

1) Kaplan MA, et al: Inability of the submaximal treadmill stress test to predict the location of coronary disease. Circulation $47: 250,1973$.

2) Yamada $\mathrm{K}$ : Body surface isopotential map. Past, present and future. Jpn Circ J 45: 1, 1981.

3) Kannel WB and Dawber TR: The electrocardiogram in neurocirculatory asthenia (anxiety neurosis or neurasthenia) : A study of 203 neurocirculatory asthenia patients and 757 healthy controls in Framingham study. Ann Intern. Med 49 : 1351, 1958.

4) Bruce RA and Horsten TR: Exercise stress testing in evaluation of patients with ischemic heart disease. Prog Cardiovasc Dis 11: 371 , 1969.

5) AHA Committee Report: Circulation 51(4): 1975.

6) Rigo P, et al: Value and limitations of segmental analysis of stress thallium myocardial imaging for localization of coronary artery disease. Circulation $61: 973,1980$.

7) Mason RE, et al: Multiple-lead exercise electrocardiography. Experience in 107 normal subjects and 67 patients with angina pectoris, and comparison with coronary cinearteriography in 84 patients. Circulation $36: 517,1967$.

8) Fox KM, et al : Relation between the precordial projection of S-T segment changes after exercise and coronary angiographic findings. Amer J Cardiol $44:$ 1068, 1979.

9) Robertson $D$, et al: The localization of coronary artery stenosis by 12 lead ECG response to graded exercise test: Support for intercoronary steal. Amer Heart J 91: 437, 1976.

10) Cabin HS and Roberts WC: Fatal cardiac arrest during cardiac catheterization for angina pectoris: Analysis of 10 necropsy patients. Amer J Cardiol 48: 1, 1981.

11) Conti CR, et al: Left main coronary artery stenosis: Clinical spectrum, pathophysiology, and management. Prog Cardiovasc Dis 22: 73, 1979.

12) Sketch $M H$, et al: Significant sex differences in the correlation of electrocardiographic exercise testing and coronary arteriograms. Amer J Cardiol $36: 169,1975$.

13) Likoff $W$, et al: Paradox of normal selective coronary arteriograms in patients considered to have unmistakable coronary heart disease. New Engl J Med 276 : 1063, 1967.

14) Waters DD, et al: Exercise testing in patients with variant angina : Results, correlation with clinical and angiographic features and prognostic significance. Circulation 65: 265, 1982.

15) Heupler FA Jr: Syndrome of symptomatic coronary arterial spasm with nearly normal coronary arteriograms. Amer J Cardiol $45: 873$, 1980.

16) MacAlpin RN : Relation of coronary arterial spasm to sites of organic stenosis. Amer J Cardiol $46: 143,1980$.

17) Wolferth CC, et al: Negative displacement of the RS-T segment in the electrocardiogram and its relationships to positive displacement: An experimental study. Amer Heart J $29: 220$, 1945.

18) Tubau JF, et al: Detection of multivessel coronary disease after myocardial infarction using exercise stress testing and multiple ECG lead system. Circulation 61: 44, 1980.

19) Dunn RF, et al: Exercise-induced ST-segment elevation. Correlation of thallium-201 myocardial perfusion scanning and coronary arteriography. Circulation 61: 989, 1980.

20) Weiner DA, et al: ST segment changes postinfarction: Predictive value for multivessel coronary disease and left ventricular aneurysm. Circulation $58: 887,1978$. 